\title{
Thoracic Myelopathy Due to a Combination of Disc Herniation, Ossified Ligamentum Flavum, and Bridging New Bone Formation in a Patient with Diffuse Idiopathic Skeletal Hyperostosis: Triple Crush! \\ Difüz Idiyopatik Skeletal Hiperostozlu Bir Hastada Torasik Miyelopatiye Neden Olan Disk Herniasyonu, Ossifiye Ligamentum Flavum ve Köprüleșen Yeni Kemik Olușumu Kombinasyonu: Üçlü Sıkıștırma!
}

\author{
Alper Murat ULAŞLI ${ }^{1}$, Abidin ERDAL ${ }^{2}$, Mahmut DUYMUŞ³, Levent Ertuğrul iNAN² \\ ${ }^{1}$ Department of $2^{\text {nd }}$ Physical Medicine and Rehabilitation, Ministry of Health, Ankara Education and Research Hospital, Ankara, Turkey \\ 2Department of Neurology, Ministry of Health, Ankara Education and Research Hospital, Ankara, Turkey \\ ${ }^{3}$ Department of Radiology, Ministry of Health, Ankara Education and Research Hospital, Ankara, Turkey
}

\begin{abstract}
Thoracic myelopathy is an uncommon condition and may be due to diffuse idiopathic skeletal hyperostosis (DISH), ossified posterior longitudinal ligament (OPLL), ossified ligamentum flavum (OLF), and disc herniation. In the present case, we discussed a patient with DISH who presented with weakness and numbness in both legs and gait difficulty after a sudden trauma. Disc herniation, bridging new bone formation, and OLF were found to contribute to severe spinal canal narrowing. Although DISH is a disease of elderly patients, the patient was relatively young with no history of diabetes and obesity. Furthermore, the patient was asymptomatic until a minor trauma. This case was reported for clinicians to be aware of this rare condition, in which prompt diagnosis and early surgical management may result in better prognosis.

Key Words: Diffuse idiopathic skeletal hyperostosis, thoracic myelopathy, ligamentum flavum
\end{abstract}

Özet

Torasik miyelopati nadir görülen bir durumdur ve difüz idiyopatik skeletal hiperostoz (DISH), ossifiye posterior longitudinal ligament, ossifiye ligamentum flavum (OLF) ve disk herniasyonlarına bağlı olabilir. Biz bu olguda her iki bacağında güçsüzlük, hissizlik ve yürüme güçlüğü ile başvuran DiSH'li bir hastayı tartıştık. Disk herniasyonu, köprüleşen yeni kemik oluşumları ve OLF ileri spinal kanal darlığına katkıda bulunmuşlardı. DiSH yaşlı insanların hastalığı olsa da, hasta nispeten gençti ve diyabet ile obezite hikayesi yoktu. Dahası hasta minör bir travma öncesine kadar asemptomatik idi. Bu olgu, klinisyenlerin hızı tanı konulup erken cerrahi uygulandığında daha iyi bir prognozla sonuçlanan bu nadir durumun farkında olması amacıyla sunulmuştur.

Anahtar Kelimeler: Difüz idiyopatik skeletal hiperostoz, torasik miyelopati, ligamentum flavum

\section{Introduction}

Diffuse idiopathic skeletal hyperostosis (DISH) is characterized by a tendency toward ossification of ligaments and characteristically affects the spine (1). DISH mostly occurs in males and in the fifth decade of the life and may be associated with systemic diseases, such as diabetes mellitus and obesity (2). The anterior longitudinal ligament is the primary site of involvement in DISH; however, ossified posterior longitudinal ligament (OPLL) and ossified ligamentum flavum (OLF) have been also described in DISH patients (3-5).

Address for Correspondence / Yazışma Adresi: Alper Murat Ulaşlı, MD, Department of $2^{\text {nd }}$ Physical Medicine and Rehabilitation, Ministry of Health, Ankara Education and Research Hospital, Ankara, Turkey Phone: +90 27224633 00-3074 E-mail: alperulasli@yahoo.com

Received/Geliş Tarihi: August/Ağustos 2012 Accepted/Kabul Tarihi: December/Aralık 2012 


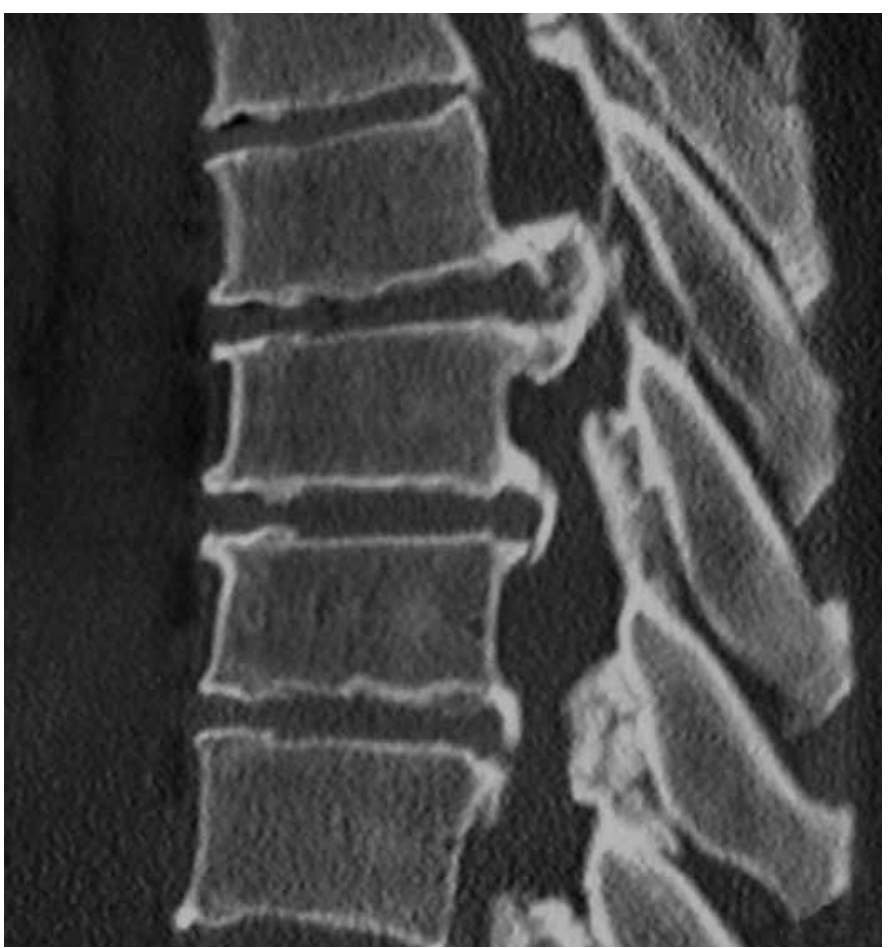

Figure 1. Sagittal computed tomography image at the level of lower thoracal vertebral bodies showing new bone formation and ossified ligamentum flavum, narrowing the spinal canal

Here, we reported a patient with DISH, who presented with weakness and numbness in both legs and gait difficulty after a sudden trauma.

\section{Case Report}

A 51-year-old man fell from a garden wall, landing on his left buttock, 1 year before admission to our clinic. He was suffering from intense lower back pain radiating to the right leg and weakness of this side. The weakness increased gradually, so that he had to use a crutch for walking the last 3 months. Physical examination revealed grade 4/5 muscle strength with manual muscle testing and mild spasticity. Deep tendon reflexes were increased throughout, with sustained clonus bilaterally. Posterior column sensations were decreased below the level of compressions, and there was diffuse numbness on the legs. He had ataxic gait, requiring a walking aid. He had no history of metabolic disease; he had only hypertension as a systemic disease. Radiographs of the thoracal and lumbar spine showed flowing osteophytes and soft-tissue ligamentous ossification, consistent with DISH and thoracic kyphosis. Serum parathormone, alkaline phosphatase, calcium, phosphorus, magnesium, and thyroidstimulating hormone levels were in the normal limits.

Computed tomography of the thoracal spine revealed vertebral fusion due to new bone formation on anterolateral aspects and beak-like outgrowth of bridging new bone formation in posterior aspects of lower thoracal vertebrae and ossification of the ligamentum flavum in multiple lower thoracal segments. As a result of OLF and posterior vertebral new bone formation,

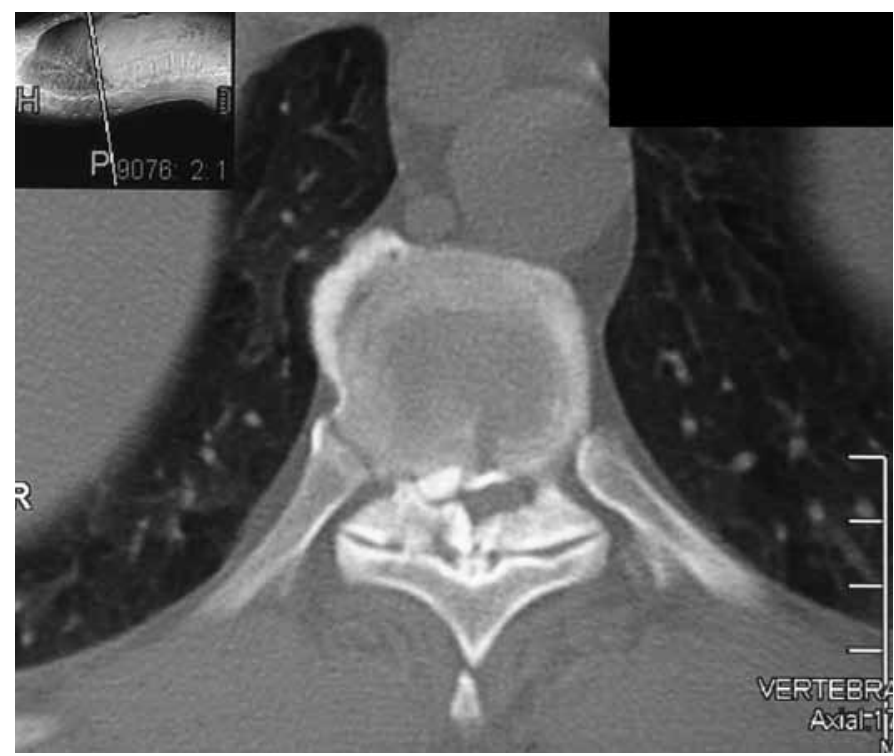

Figure 2. Axial CT image shows new bone formation in both anterolateral and posterior aspects of the vertebral column and ossified ligamentum flavum causing narrowed spinal canal

the spinal canal was severely narrowed and the spinal cord was compressed, most prominently in the Th 10 and 11 vertebral segments (Figures 1 and 2). Thoracal magnetic resonance imaging (MRI) showed that the spinal cord was compressed with increased T2 signal intensity, indicating cord edema in the narrowed spinal canal. Intervertebral disc herniations accompanying the spinal canal narrowing, most prominent between Th 10 and 11 , were also noted (Figure 3 ). The patient was then referred to a neurosurgery clinic for decompression surgery.

\section{Discussion}

Thoracic spinal canal stenosis is a rare condition and may be due to DISH, OPLL, OLF, and disc herniation (6). DISH is an asymptomatic condition in general; however, it can present with neurological symptoms due to compression of the spinal cord. Qunfeng et al. (4) reported neurological deficits due to OPLL and OLF causing spinal cord compression associated with DISH. Reisner and Wilson also reported that OLF associated with DISH had an important role in the development of neurologic deficits, mainly in the thoracic spine $(7,8)$.

Ossified ligamentum flavum was most commonly reported in the lower third of the thoracic spine, and the most common symptomatic level was Th10-Th11 $(6,9)$. According to Smith et al., this region appears to be particularly prone to degenerative processes due to the high tensile force present in the posterior column (10). Thoracic kyphosis may contribute to alteration of mechanical stresses at this area and contribute to the development of OLF (11). In our case, the most prominent spinal canal narrowing and spinal cord compression were in the Th10 and Th11 vertebral segments; additionally, thoracic kyphosis was present, which may contribute to the pathogenesis of OLF.

The ossification of the ligamentum flavum was attributed to trauma, DISH, ankylosing spondylitis, hemachromatosis, fluoro- 


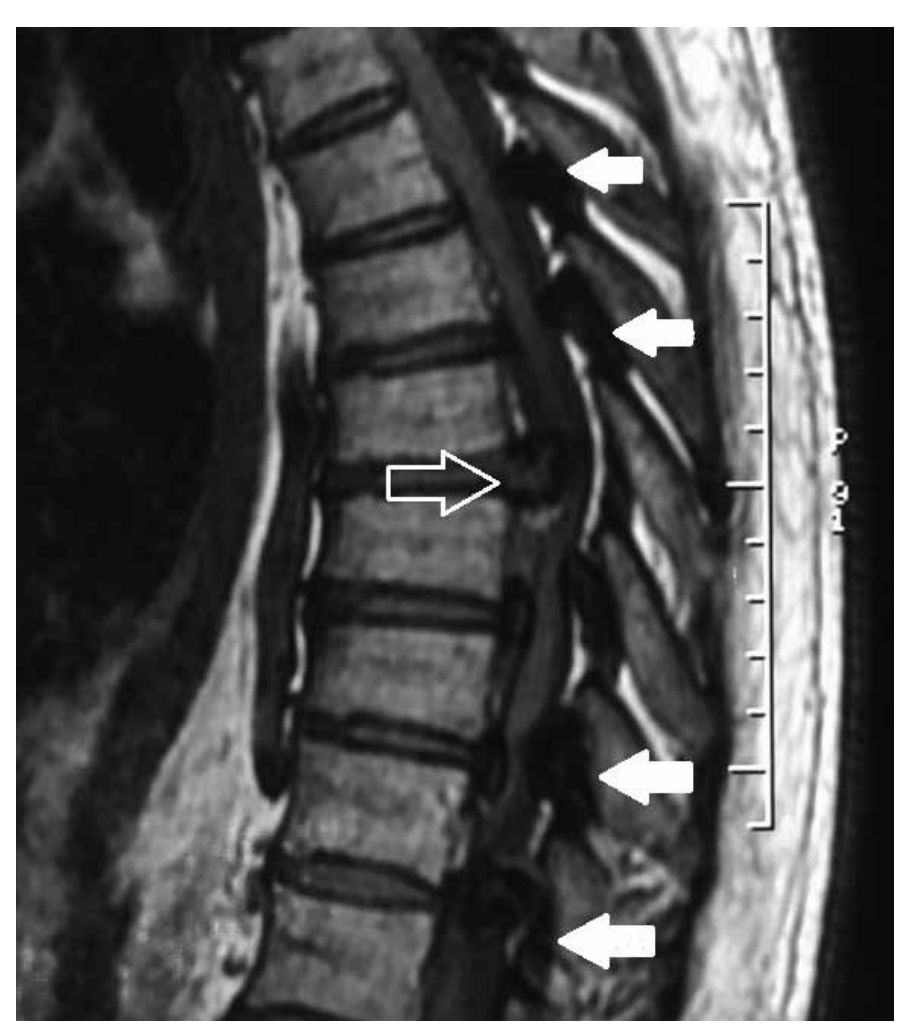

Figure 3. Sagittal MR image at the level of lower thoracal vertebral bodies shows discoosteogenic material (open white arrow) and ossified ligamentum flavum in multiple lower thoracal segments with compressed spinal cord (white arrows).

sis, and disorders of calcium and phosphorus (12). Fong et al. (6) described two possible presentations for OLF. The first one involves chronic spinal cord compression over a long period of time and presents with unsteady gait, difficulty with balance and climbing stairs, and neurogenic claudication followed by progressively increasing spastic paraparesis. The physical examination may reveal upper motor neuron and posterior column signs. In the second one, OLF can present as acute myelopathy after a minor trauma, with a sudden compromise in an asymptomatic but narrowed spinal canal by hematoma and edema. In the case reported here, the patient's symptoms occurred after a relatively minor trauma and progressed within 1 year until admission to our clinic.

Ehara et al. (3) found that DISH was present in 27 out of 109 cases of OPLL (25\%) and in 4 out of 18 cases of OLF (21\%). DISH predominantly occurred in the thoracolumbar spine and OLF in the lower thoracic spine, as in our case. Fong et al. (6) reported a case series of five patients with thoracic myelopathy secondary to ligamentum flavum ossification, but they did not specify any co-existing disease. In another study evaluating thoracic cord compression due to OLF, only 1 of the 15 patients was diagnosed with DISH (12). We noticed two case reports in which OLF associated with DISH causing myelopathy was described in the literature $(7,8)$. In the present case, disc herniation together with bridging new bone formation on the anterior side and OLF on the posterior side of the spinal canal caused severe narrowing in a patient with DISH, and OPLL was not a part of this process.

In the case of cervical involvement, DISH may present with neck pain, limitation of movement, and dysphagia and also rarely with aspiration, dyspnea, and laryngeal stridor (13). Eser et al. (14) reported a patient who developed posttraumatic quadriparesis and was diagnosed with central cord syndrome and DISH. The patient presented here had no complaints indicating cervical involvement, and he had paraparesis after trauma.

Prompt surgical intervention and appropriate rehabilitation management play key roles in improving the functional outcome of myelopathy caused by OLF. Surgical decompression is the only therapy, and the shorter time until surgery, the better neurological prognosis $(15,16)$.

\section{Conclusion}

In conclusion, we presented a patient with a severely narrowed spinal canal and compressed spinal cord due to bridging new bone formation, disc herniation, and OLF. Although DISH is a disease of elderly patients, the patient was relatively young with no history of diabetes and obesity, but he had a severely involved spinal canal. Furthermore, the patient was asymptomatic until a minor trauma. Thus, clinicians should be aware of this rare condition in which prompt diagnosis and early surgical management may result in better prognosis.

Informed Consent: Written informed consent was obtained from patient who participated in this study.

Peer-review: Externally peer-reviewed.

Author Contributions: Concept - A.M.U.; Data Collection and/or Processing - A.E., M.D.; Literature Review - A.E., M.D.; Writer - A.M.U.; Critical Review - L.E.I.

Conflict of Interest: No conflict of interest was declared by the authors.

Financial Disclosure: The authors declared that this study has received no financial support.

Hasta Onamı: Yazılı hasta onamı bu çalışmaya katılan hastadan alınmıştır.

Hakem değerlendirmesi: Dış bağımsız.

Yazar Katkıları: Fikir - A.M.U.; Veri toplanması ve/veya işlemesi - A.E., M.D.; Literatür taraması - A.E., M.D.; Yazıyı yazan - A.M.U.; Eleştirel Inceleme - L.E.I.

Çıkar Çatışması: Yazarlar çıkar çatışması bildirmemişlerdir.

Finansal Destek: Yazarlar bu çalışma için finansal destek almadıklarını beyan etmişlerdir.

\section{References}

1. Miyazawa N, Akiyama I. Ossification of the ligamentum flavum of the cervical spine. J Neurosurg Sci 2007;51:139-44. 
2. Resnick D, Shaul SR, Robins JM. Diffuse idiopathic skeletal hyperostosis (DISH): Forestier's disease with extraspinal manifestations. Radiology 1975;115:513-24.

3. Ehara S, Shimamura T, Nakamura R, Yamazaki K. Paravertebral ligamentous ossification: DISH, OPLL and OLF. Eur J Radiol 1998;27:196-205. [CrossRef]

4. Guo Q, Ni B, Yang J, Zhu Z. Simultaneous ossification of the posterior longitudinal ligament and ossification of the ligamentum flavum causing upper thoracic myelopathy in DISH: case report and literature review. Eur Spine J 2011;20:195-201. [CrossRef]

5. Kocer A, Gozke E, Tasali N. Thoracic myelopathy due to enlarged Ossified ligaments (Japanese disease) in a Turkish female patient. J Neurol Sci [Turk] 2005;22:69-73.

6. Fong SY, Wong HK. Thoracic myelopathy secondary to ligamentum flavum ossification. Ann Acad Med Singapore 2004;33:340-6.

7. Reisner A, Stiles RG, Tindall SC. Diffuse idiopathic skeletal hyperostosis causing acute thoracic myelopathy: a case report and discussion. Neurosurgery 1990;26:507-11. [CrossRef]

8. Wilson FM, Jaspan T. Thoracic spinal cord compression caused by diffuse idiopathic skeletal hyperostosis (DISH). Clin Radiol 1990;42:133-5. [CrossRef]

9. Okada K, Oka S, Tohge K, Ono K, Yonenobu K, Hosova T. Thoracic myelopathy caused by ossification of ligamentum flavum. Clinicopathologic study and surgical treatment. Spine 1991;16:280-7. [CrossRef]
10. Smith DE, Godersky JC. Thoracic spondylosis: an unusual cause of myelopathy. Neurosurgery 1987;20:589-93. [CrossRef]

11. Hanakita J, Suwa H, Ohta F, Nishi S, Sakaida H, Tihara K. Neuroradiological examination of thoracic radiculomyelopathy due to ossification of ligamentum flavum. Neuroradiology 1990;32:38-42. [CrossRef]

12. Jakayumar PN, Devi BI, Bhat DI, Das BS. Thoracic cord compression due to ossified hypertrophied ligamentum flavum. Neurol India 2002;50:286-9.

13. Ayçiçek A, Eser O, Haktanır A, Boyacı G, Altuntaş A. Servikal vertebral osteofit nedeniyle oluşan disfaji: Olgu sunumu. Bakırköy Tıp Dergisi 2009;5:117-9.

14. Eser $O$, Aslan A, Coşar M, Albayrak R. Yaygın Idiopatik iskelet hiperostozu (DISH): Olgu sunumu. Van Tıp Dergisi 2006;13:103-5.

15. Shiguematsu FY, de Souza EC, Zimmermann AF, Castro GR, Pereira IA, Neves FS. Thoracic myelopathy due to calcification of the ligamentum flavum with hyperproteinorachia and responsive to steroid therapy: case report. Rev Bras Reumatol 2012;52:438-46.

16. Miyakoshi N, Shimada $Y$, Suzuki T, Hongo M, Kasukawa Y, Okada $K$ et al. Factors related to long-term outcome after decompressive surgery for ossification of the ligamentum flavum of the thoracic spine. J Neurosurg 2003;99:251-6. 